\title{
CHARACTERIZATION AND QUANTITATION OF 3-ALKYLTHYMIDINES FROM REACTIONS OF MUTAGENIC PROPYLENE OXIDES WITH THYMIDINE
}

\author{
ZORA DJURIĆ and JOSEPH E. SINSHEIMER* \\ College of Pharmacy, University of Michigan, Ann Arbor, MI 48109 (U.S.A.) \\ (Received June 20th, 1984) \\ (Revision received September 3rd, 1984) \\ (Accepted September 11th, 1984)
}

\section{SUMMARY}

Thymidine was reacted in methanol with four epoxides of varying mutagenicities: propylene oxide, glycidol, epichlorohydrin and trichloropropylene oxide. A single product was detected with each epoxide, and these products had the same retention times on silica high pressure liquid chromatography (HPLC). UV spectra of the products identified them as 3-alkylthymidines, and this was confirmed by infrared (IR) and nuclear magnetic resonance (NMR) spectra. Mass spectra (MS) analysis showed the products to be consistent with attachment at the least substituted carbon of the epoxide. Formation of 3-alkylthymidines correlated to Taft $\sigma^{*}$ electron withdrawing values for the substituents on the epoxides and mutagenicities in strain TA100 of the Ames Assay.

Key words: Thymidine alkylations - Propylene oxides - Mutagenicity Taft $\sigma^{*}$ - Site of alkylation

\section{INTRODUCTION}

This work was undertaken as a step towards learning more about the importance of specific site adducts in the mutagenesis of propylene oxides and to gain reference compounds for DNA alkylation studies. We are interested in extending the studies on structure-mutagenicity relationships

*To whom correspondence should be addressed.

Abbreviatons: DMSO, dimethylsulfoxide; EC, epichlorohydrin; GL, glycidol; HPLC, high pressure liquid chromatography; HSD, homonuclear spin decoupling; IR, infrared; NMR, nuclear magnetic resonance; MS, mass spectra; PO, propylene oxide; TCPO, trichloropropylene oxide. 
found in our laboratory for aliphatic epoxides $[1,2]$ as well as the research existing on the interaction of propylene oxides with nucleosides [3-8]. In an investigation of the reactions of propylene oxides with deoxycytidine [8] we found that although there were differences in the extent of alkylation at the nitrogen and oxygen sites for each epoxide, total reactivity with deoxycytidine correlated to mutagenicity. In a continuation of this work, thymidine is an interesting deoxynucleoside for specific site alkylation studies since the $\mathrm{N-3}$ and $\mathrm{O}^{4}$ sites are involved in hydrogen bonding in DNA while the $\mathrm{O}^{2}$ is not. It was the purpose of the present investigation to quantitate and identify the alkylation products obtained from thymidine reactions with propylene oxide (PO), glycidol (GL), epichlorohydrin (EC) and trichloropropylene oxide (TCPO) by their UV spectra and to confirm this identification by IR, NMR and MS spectra. It was of interest to determine the site of alkylation on thymidine as well as to distinguish which epoxide carbon is involved in the attachment. The extent of reaction with thymidine was correlated to Taft $\sigma^{*}$ electron withdrawing values [9] for the substituents on the epoxides and mutagenicities in strain TA100 of the Ames assay [10].

\section{MATERIALS AND METHODS}

\section{Chemicals}

The propylene oxides were purchased from Aldrich Chemical Co. (Milwaukee, WI) and gold label thymidine was purchased from Sigma Chemical Co. (St. Louis, MO). Compounds were dissolved in gold-label, 99.9\% DMSO- $d_{6}$ from Aldrich Chemical Co. for NMR spectra. Infrared quality potassium bromide was from Harshaw (Solon, $\mathrm{OH}$ ).

\section{Reactions}

For the comparative reactivity study, reactions were prepared by dissolving accurately weighed thymidine in methanol and adding $0.500 \mathrm{mmol}$ epoxide in methanol per $\mathrm{mg}$ thymidine. The final concentration of thymidine was $2 \mathrm{mg} / \mathrm{ml}$. Reactions in tightly sealed vials were placed in a $37^{\circ} \mathrm{C}$ shaking water bath for $48 \mathrm{~h}$.

The preparative reactions were performed in methanol using $2.25 \mathrm{ml}$ methanol and $0.25 \mathrm{ml}$ epoxide per $10 \mathrm{mg}$ thymidine. These reaction mixtures were placed in the shaker bath for $72 \mathrm{~h}$.

\section{Chromatography}

Thin-layer chromatography, used to monitor reactions, was on prescored $2 \times 10-\mathrm{cm}, 250-\mu \mathrm{m}$ silica GHLF Uniplates (Analtech, Newark, DE). The solvent system was methylene chloride/methanol $(3: 1)$. Unreacted thymidine had a $R_{\mathrm{f}}$-value of 0.63 , and $R_{\mathrm{f}}$-values for the products from each reaction are as follows: thymidine-PO, 0.77; thymidine-GL, 0.71 ; thymidineEC, 0.73; thymidine-TCPO, 0.79 .

Analytical HPLC was on a Whatman (Clifton, NJ) Partisil PXS 10/25 
$(4.6 \times 250 \mathrm{~mm})$ column which was preceded with a guard column $(4.6 \times$ $50 \mathrm{~mm}$ ) packed with HC Pellosil, also from Whatman. The mobile phase was methylene chloride/methanol $(20: 1)$ with a flow rate of $1.3 \mathrm{ml} / \mathrm{min}$. Samples were mixed with an equal volume of methanol containing pyridine $\left(5 \times 10^{-4} \mathrm{v} / \mathrm{v}\right)$ prior to injection of $10-\mu \mathrm{l}$ aliquots onto the column. Products are referred to as labelled in Fig. 1 of the HPLC chromatograms.

Semi-preparative silica HPLC was on a Whatman Partisil PXS Magnum 9 $(9.4 \times 500 \mathrm{~mm})$ column preceded with a guard column $(4.6 \times 100 \mathrm{~mm})$ packed with HC Pellosil. The mobile phase was methylene chloride/methanol $(90: 10)$ with a flow rate of $3.5 \mathrm{ml} / \mathrm{min}$ and detection was at $254 \mathrm{~nm}$. Each injection of undiluted reaction mixture contained approx. $1.5 \mathrm{mg}$ starting material. The EC and TCPO reactions had high enough product yields for analysis by IR, NMR and MS methods in addition to UV methods. Fractions collected were evaporated under a stream of nitrogen prior to direct probe MS or dilution with DMSO- $d_{6}$ for NMR. For IR analyses, $30 \mathrm{mg} \mathrm{KBr}$ was added to a solution containing approx. $0.1 \mathrm{mg}$ deoxynucleoside prior to evaporating the sample to dryness.

\section{UV spectra}

UV spectra were taken on a Hewlett Packard (Palo Alto, CA) model 8450A UV/VIS spectrophotometer. Dried samples were diluted in water as necessary to obtain absorbance maxima between 0.5 and 1.0. Spectra were obtained at acidic pH by mixing the aqueous samples with an equal volume of $0.1 \mathrm{M} \mathrm{HCl}$ or at basic $\mathrm{pH}$ by mixing with an equal volume of $0.1 \mathrm{M} \mathrm{NaOH}$. Aliquots of preparatively collected fractions were mixed with an equal volume of $12 \mathrm{M} \mathrm{HCl}$ to observe any changes in the spectrum $18 \mathrm{~h}$ after such treatment.

\section{IR spectra}

IR spectra were obtained on a Perkin-Elmer (Norwalk, CN) model 281 spectrophotometer equipped with their model 3600 Data Station. Samples in the HPLC mobile phase were dried under a stream of nitrogen after adding approximately $20 \mathrm{mg} \mathrm{KBr}$ and were pressed into paper microframes ( $2 \times 10 \mathrm{~mm}$ aperature). The most prominant absorbance bands for the reaction products EC- 1 and TCPO- 1 as well as unreacted thymidine, are as follows:

EC-1, $3440 \mathrm{~cm}^{-1}$, strong (s); 2935, medium (m); 1704, s; 1672, shoulder (sh); 1638, s; 1474, s; 1375, weak (w); 1273, m; 1096, w; 1050, w; 768, w; $670, \mathrm{w}$.

TCPO-1, 3400, s; 2934, s; 1707, m; 1660, sh; $1640, \mathrm{~s} ; 1477, \mathrm{~s} ; 1269, \mathrm{~m}$; 1197, w; 1099, m; 1069, sh; 867, w; 791, m; 769, sh.

TCPO-2 )thymidine), $3420, \mathrm{~s} ; 3220 \mathrm{w} ; 2959 \mathrm{w} ; 2928$, w; 1719 and 1733 , doublet, s; 1663, s;1482, w; 1364, w; 1320, w; 1296, sh; 1273, m; 1198, w; 1102, w; 1050, w; 764, w; 748, w. 


\section{NMR spectra}

Proton NMR spectra were taken on a Bruker $360 \mathrm{MHz}$ Fourier Transform instrument. Samples contained about $1 \mathrm{mg}$ of deoxynucleoside dissolved in $0.5 \mathrm{ml} \mathrm{DMSO}-d_{6}$. The proton chemical shifts of EC-1, TCPO-1 and TCPO-2 in DMSO- $d_{6}$ as well as after $\mathrm{D}_{2} \mathrm{O}$ exchange and with homonuclear spin decoupling (HSD) are identified in the following listing:

EC-1, in DMSO- $d_{6}, \delta 7.76(\mathrm{~s}, 1,6 \mathrm{H}) ; 6.18\left(\mathrm{t}, \mathrm{J}=6.8 \mathrm{~Hz}, 1,1^{\prime} \mathrm{H}\right) ; 5.32$ (d, broad, 1, COH); 5.24 (d, broad, 1, 3' $\mathrm{OH}) ; 5.03\left(\mathrm{~m}\right.$, broad, $\left.1,5^{\prime} \mathrm{OH}\right) ; 4.22$ $\left(\mathrm{m}, 1,3^{\prime} \mathrm{H}\right) ; 3.99\left(\mathrm{~m}, 2, \mathrm{CClCH}_{2}\right) ; 3.77\left(\mathrm{~m}, 2,4^{\prime} \mathrm{H}\right.$ and $\left.\mathrm{CH}\right) ; 3.62-3.41(\mathrm{~m}, 4$, $5^{\prime} \mathrm{H}$ and $\left.\mathrm{CH}_{2}\right) ; 2.08\left(\mathrm{~m}, 2,2^{\prime} \mathrm{H}\right) ; 1.81\left(\mathrm{~s}, 3,5-\mathrm{CH}_{3}\right)$, HSD at 3.45 simplified the multiplet at $3.62-3.41$, HSD at 3.99 simplified the multiplets at 3.77 and $3.62-3.41$ and the doublet at 5.32 became a singlet, $\mathrm{D}_{2} \mathrm{O}$ exchange, $7.68(\mathrm{~s}, 1,6 \mathrm{H}) ; 6.13\left(\mathrm{t}, \mathrm{J}=6.8,1,1^{\prime} \mathrm{H}\right) ; 4.21\left(\mathrm{q}, \mathrm{J}=3.4,1,3^{\prime} \mathrm{H}\right) ; 3.97$ $\left(\mathrm{m}, 2, \mathrm{CH}_{2}\right) ; 3.76\left(\mathrm{~m}, 2,4^{\prime} \mathrm{H}\right.$ and $\left.\mathrm{CH}\right) ; 3.57-3.53\left(\mathrm{~m}, 4,5^{\prime} \mathrm{H}\right.$ and $\left.\mathrm{CH}_{2}\right)$; $2.08\left(\mathrm{~m}, 2,2^{\prime} \mathrm{H}\right), 1.78\left(\mathrm{~s}, 3,5-\mathrm{CH}_{3}\right)$, HSD at 3.76 , simplified the multiplet at $3.53-3.57$ and at 3.98 and the quartet at 4.21 became a triplet $(\mathrm{J}=3.9)$, HSD at 3.55 simplified the multiplet at 3.96 .

TCPO-1, in DMSO- $d_{6}, \delta 7.81(\mathrm{~s}, 1,6 \mathrm{H}) ; 6.78(\mathrm{broad}, 1, \mathrm{COH}) ; 6.20(\mathrm{t}$, $\left.\mathrm{J}=6.7,1,1^{\prime} \mathrm{H}\right) ; 5.2\left(\right.$ broad, $2,3^{\prime} \mathrm{OH}$ and $\left.5^{\prime} \mathrm{OH}\right) ; 4.44\left(\mathrm{~m}, 2, \mathrm{CH}_{2}\right) ; 4.24$ $\left(\mathrm{q}, \mathrm{J}=4.2,1,3^{\prime} \mathrm{H}\right) ; 4.04(\mathrm{~m}, 1, \mathrm{CH}) ; 3.78\left(\mathrm{q}, \mathrm{J}=3.3,1,4^{\prime} \mathrm{H}\right) ; 3.57(\mathrm{~m}, 2$, $\left.5^{\prime} \mathrm{H}\right) ; 2.09\left(\mathrm{~m}, 2,2^{\prime} \mathrm{H}\right) ; 2.05$ (extraneous); $1.83\left(\mathrm{~s}, 3, \mathrm{CH}_{3}\right), \mathrm{D}_{2} \mathrm{O}$ exchange, $7.74(\mathrm{~s}, 1,6 \mathrm{H}) ; 6.15\left(\mathrm{t}, \mathrm{J}=6.4,1,1^{\prime} \mathrm{H}\right) ; 4.41\left(\mathrm{~m}, 2, \mathrm{CH}_{2}\right) ; 4.21(\mathrm{q}, \mathrm{J}=3.6$, $\left.1,3^{\prime} \mathrm{H}\right) ; 4.05(\mathrm{~m}, 1, \mathrm{CH}) ; 3.78\left(\mathrm{q}, \mathrm{J}=3.7,4^{\prime} \mathrm{H}\right) ; 3.56\left(\mathrm{~m}, 2,5^{\prime} \mathrm{H}\right) ; 2.09$ (m, 2, 2' $\mathrm{H}) ; 2.03$ (extraneous); $1.80\left(\mathrm{~s}, 3, \mathrm{CH}_{3}\right)$, HSD at 2.03 had no effect, HSD at 4.05 simplified the multiplet at 4.41 , HSD at 4.44 simplified the multiplet at 4.05 , HSD at 2.09 simplified the quartet at 4.21 to a doublet $(\mathrm{J}=2.5)$ and the triplet at 6.15 became a doublet $(\mathrm{J}=2.5)$.

TCPO-2 (thymidine), DMSO-d ${ }_{6}, \delta 11.2$ (broad, 1, NH); 7.68 (s, 1, H6); $6.15\left(\mathrm{t}, \mathrm{J}=6.9,1,1^{\prime} \mathrm{H}\right) ; 5.1\left(\mathrm{broad}, 2,3^{\prime} \mathrm{OH}\right.$ and $\left.3^{\prime} \mathrm{OH}\right) ; 4.22(1 \mathrm{H}, \mathrm{q}, \mathrm{J}=2.6$, $\left.1,3^{\prime} \mathrm{H}\right) ; 3.74\left(\mathrm{q}, \mathrm{J}=3.2,1,4^{\prime} \mathrm{H}\right) ; 3.55\left(\mathrm{~m}, 2,5^{\prime} \mathrm{H}\right) ; 2.05\left(\mathrm{~m}, 2,{ }^{\prime} \mathrm{H}\right) ; 1.75$ $\left(\mathrm{s}, 3, \mathrm{CH}_{3}\right), \mathrm{D}_{2} \mathrm{O}$ exchange, $7.66(\mathrm{~s}, 1,6 \mathrm{H}) ; 6.12\left(\mathrm{t}, \mathrm{J}=6.9,1,1^{\prime} \mathrm{H}\right) ; 4.21$ $\left(\mathrm{q}, \mathrm{J}=3.9,1,3^{\prime} \mathrm{H}\right) ; 3.74\left(\mathrm{q}, \mathrm{J}=3.4,1,4^{\prime} \mathrm{H}\right) ; 3.54\left(\mathrm{~m}, 2,5^{\prime} \mathrm{H}\right) ; 2.05(\mathrm{~m}, 2$, $\left.2^{\prime} \mathrm{H}\right) ; 1.75\left(\mathrm{~s}, 1, \mathrm{CH}_{3}\right)$.

\section{$M S$}

A Finnigan model 4023 instrument was used to obtain electron ionization spectra at $70 \mathrm{eV}$. The masses obtained for EC-1, TCPO-1 and TCPO-2 above $1 \%$ relative intensity, except where indicated, follow: $m / z$ (relative intensity) with losses from ${ }^{35} \mathrm{Cl}$ isotopic masses designated from the molecular ion (M), pyrimidine base (B), deoxysugar (S) and alkyl side chain (R):

EC-1, $336(0.01) ; 334(0.04) \mathrm{M} ; 293(0.04) ; 289(0.07) ; 287(0.10) ; 256$ (0.07); $247(0.40) \mathrm{B}+30 ; 246(0.06) ; 245(1.05) \mathrm{B}+28 ; 221(2.44) ; 220$ (2.20); 219 (8.62) B + 2; 218 (4.68) B + 1; 201 (1.84); 183 (7.10); 182 (29.9) B-Cl; 170 (1.08); 169 (15.9) $\mathrm{BH}-\mathrm{ClCH}_{2} ; 165$ (6.85); 153 (1.53); 142 (1.93); 140 (19.4) $\mathrm{BH}-\mathrm{CClH}_{2} \mathrm{CHO} ; 139$ (5.13) $\mathrm{B}-\mathrm{CClH}_{2} \mathrm{CHO} ; 138$ (1.58); 
129 (2.11); 128 (3.74); 127 (51.7) $\mathrm{BH}_{2}-\mathrm{R} ; 126$ (7.54); 122 (3.09); 118 (5.34); 117 (100) S; 116 (1.75); 111 (2.60); 110 (47.5) B- $\mathrm{RCH}_{3} ; 109$ (1.19); $100(2.97) ; 99(39.0) \mathrm{S}-18$.

TCPO-1, 406 (0.01); 405 (0.02); 404 (0.03); 403 (0.02); 402 (0.03) M; $373(0.01) ; 371(0.01)$ M-30; $368(0.01) ; 366(0.01) ; 315(0.32) \mathrm{B}+30 ; 313$ (0.35) B + 28; $289(2.01) ; 288(1.02) ; 287(2.12) \mathrm{B}+2 ; 253(1.37) ; 252$ (2.12); 221 (2.13); 250 (3.08) B-Cl; 217 (1.59); 215 (4.82) $\mathrm{B}-\mathrm{Cl}_{2} ; 170$ (1.12); 169 (13.2) $\mathrm{BH}-\mathrm{CCl}_{3} ; 167$ (1.14); 165 (2.01); 150 (1.30); 140 (4.34) BH$\mathrm{CCl}_{3} \mathrm{CHO} ; 139$ (9.04) B-CCl 3 CHO; $138(1.50) ; 127$ (1.42) $\mathrm{BH}_{2}-\mathrm{R} ; 118(7.74)$; 117 (100) S; 116 (2.33); 114 (1.35); 112 (2.76); 111 (3.56); 110 (27.8) B-RCH ${ }_{3} ; 109(2.08) ; 100(1.98) ; 99(32.7)$ S-18.

TCPO-2 (thymidine), 243 (1.0); $242(2.90) \mathrm{M} ; 206$ (1.16); 193 (0.55); 181 (0.44); 168 (0.59); 156 (1.23) B + 31; 155 (0.42) B + 30; 154 (2.60); 153 (4.52) B + 28; $152(0.63) ; 151(0.61) ; 150$ (2.91); 135 (1.18); 128 (3.28); 127 (43.6) B + 2; 126 (39.6) B + 1; $122(2.60) ; 119$ (1.34); 118 (9.60); 117 (100) S; 116 (3.38); 112 (1.02); 111 (1.66); 110 (18.9) B-CH 109 (2.80); 100 (2.28); 99 (37.2) S-18.

\section{RESULTS AND DISCUSSION}

\section{Chromatography}

The thymidine reaction products could be separated on either cation exchange or reverse phase HPLC systems using buffers for elution, but the silica system (Fig. 1) offered better resolution and fractions collected for spectral analysis were in a volatile mobile phase. The semi-preparative HPLC separation was similar to the analytical separation and was used for collecting products from the reactions of the most reactive epoxides, EC and TCPO. Confirmation of the HPLC results that only one product was formed with each epoxide was obtained by TLC.

\section{UV spectra}

The UV spectra of thymidine derivatives are unique $[11,12]$ and allow for a reliable identification of the site of alkylation on thymidine. Distinction between $\mathrm{O}$-alkyl derivatives and the $\mathrm{N}-3$ alkyl derivative can be made on the basis of peak maxima $[10,12]$ as well as changes in the spectrum upon strong acid treatment $[10,13]$.

All of the products had the same retention times as well as the same UV peak maxima and $254 / 280 \mathrm{~nm}$ absorbance ratios at acidic, neutral and basic $\mathrm{pH}$ values. These were identical with the spectra of EC-1 shown in Fig. 2 and agree with published spectra $[10,12]$ of 3 -alkylthymidine derivatives. The $254 / 280 \mathrm{~nm}$ absorbance ratios $[14,15]$ for all spectra were essentially unity and indicate the absence of $\mathrm{O}$-alkylation because $\mathrm{O}$-alkyl derivatives have different absorbances at those wavelengths $[11,12]$. The preparatively collected products, EC-1 and TCPO-1, were subjected to $6 \mathrm{M} \mathrm{HCl}$ treatment. They did not exhibit a change in their UV spectra after $18 \mathrm{~h}$ of such treatment, unlike what would be expected for $O$-alkyl derivatives $[11,13]$. 

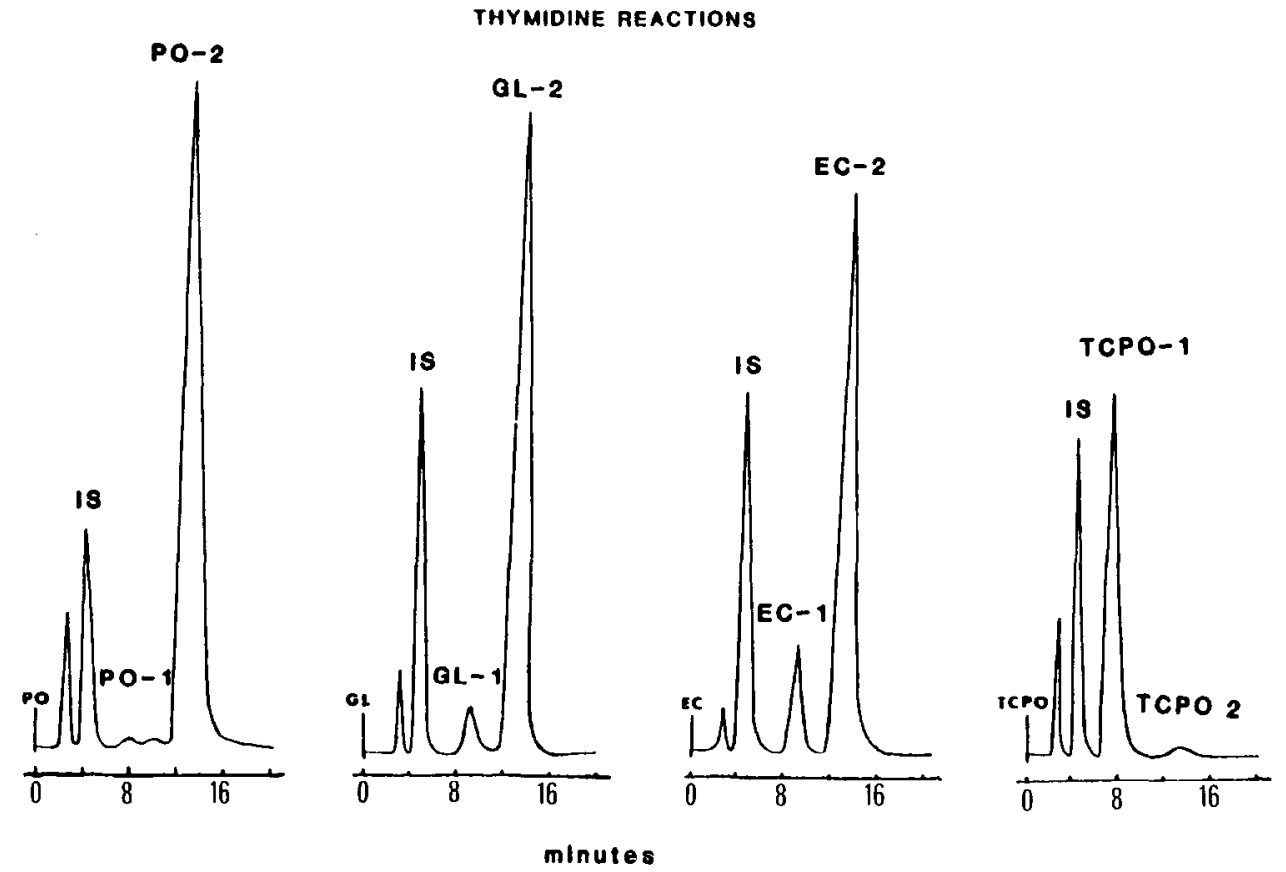

Fig. 1. Silica HPLC separations of thymidine reactions with PO, GL, EC or TCPO. The mobile phase is methylene chloride/methanol $(20: 1)$ at a flow rate of $1.3 \mathrm{ml} / \mathrm{min}$. The internal standard (IS) is pyridine and unreacted thymidine elutes at $14 \mathrm{~min}$.

\section{IR spectra}

The IR spectra (Materials and Methods) of the products EC-1 and TCPO-1 which were formed in sufficient quantities for preparative isolation, helped confirm the UV evidence for N-3 alkylation of thymidine. For these products there was an additional absorbance band in the region $1740-1630 \mathrm{~cm}^{-1}$ that is not present in unreacted thymidine (TCPO-2). This is similar to the comparison of 3-methyluridine with uridine [17]. For both of the products this additional band could be indicative of $\mathrm{N}-3$ alkylation since a tertiary amide is expected to absorb in the $1670-1630 \mathrm{~cm}^{-1}$ region [18]. Another indication of $\mathrm{N}-3$ alkylation is absence of the band at $3220 \mathrm{~cm}^{-1}$ for both of the products. The $\mathrm{NH}$ stretching vibration for the $-\mathrm{CO}-\mathrm{NH}-\mathrm{CO}-$ group in uridine occurs at $3155 \mathrm{~cm}^{-1}$ [19] so that the band at $3220 \mathrm{~cm}^{-1}$ in the spectrum of unreacted thymidine could be assigned to this absorption. Both of the products had very similar spectra except that the $\mathrm{C}-\mathrm{Cl}$ absorption at $791 \mathrm{~cm}^{-1}$ [20] for the TCPO product is stronger than for the EC product.

NMR spectra

The NMR spectrum of TCPO-2 was identified as unreacted thymidine according to existing literature for NMR of nucleosides [21-23], and 


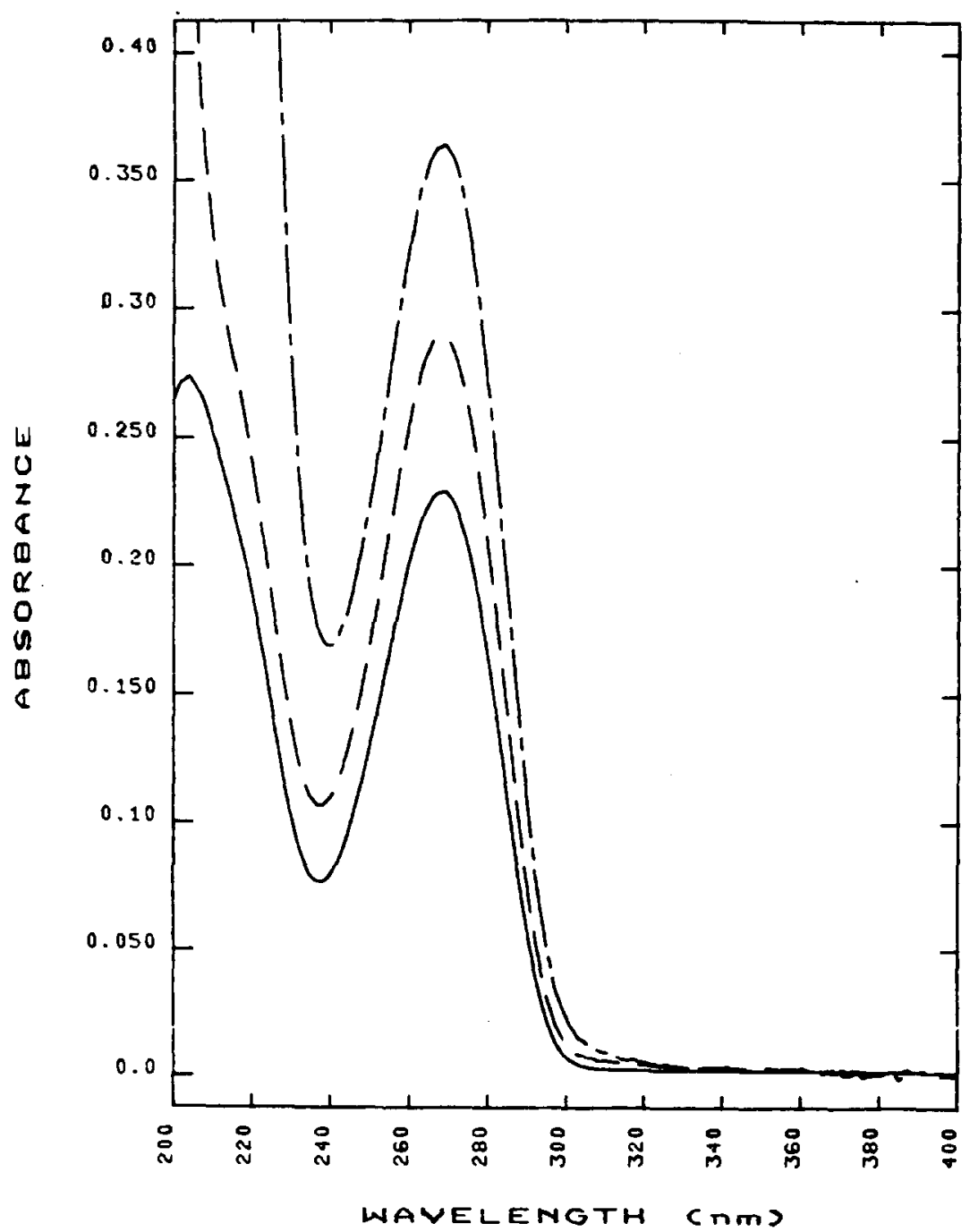

Fig. 2. UV spectra of the thymidine-EC reaction product at neutral $(-)$, acidic $(--)$ and (-- - ) pH-values.

assignments for the products were made on the basis of this literature as well as by decoupled and $\mathrm{D}_{2} \mathrm{O}$ exchanged spectra (Materials and Methods). The deshielding effect of increasing chlorine substitution [24] on the side chain is evident from a comparison of the chemical shifts of the alkyl side chain protons in EC-1 and TCPO-1. Alkylation at the N-3 is indicated by absence of the NH proton in the spectra. Thus, both EC-1 and TCPO-1 have spectra consistent with 3-alkylthymidines. 


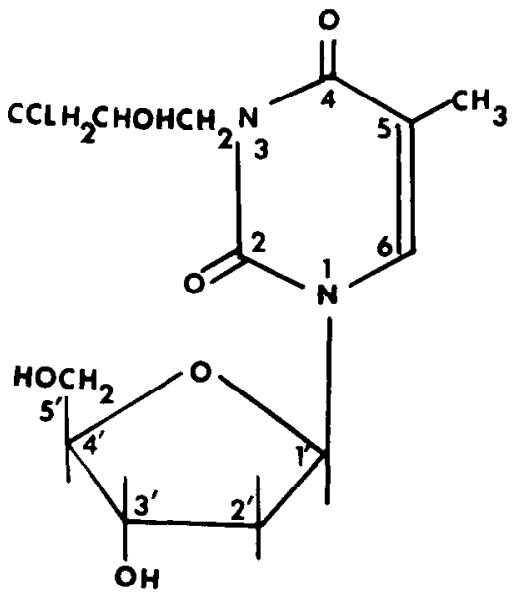

Fig. 3. Structure of thymidine alkylated at the N-3 site by EC.

$M S$

The mass spectra clearly show the molecular ions of EC-1, TCPO-1 and thymidine (TCPO-2), with higher masses for the chlorinated derivatives detected as expected for the presence of ${ }^{37} \mathrm{Cl}$. Characteristic masses for nucleosides are present (Materials and Methods), including molecular ion-30, $\mathrm{B}+30, \mathrm{~B}+28, \mathrm{~B}+2$, and deoxysugar-18 $[25,26]$, as well as masses due to fragmentation of alkyl side chain.

Alkylation is expected to occur at the least substituted, or normal, carbon of the epoxide by a $S_{N} 2$ mechanism [27] to yield a structure as shown in Fig. 3. Analogous to the fragmentation of normally alkylated products from the reaction of PO with adenosine or quanosine [4], losses characteristic of normal alkylation were found for the thymidine alkylation products. Both $\mathrm{m} / z 169$ and 140 for losses of $\mathrm{CCl}_{3}$ or $\mathrm{CCl}_{3} \mathrm{CHO}$ from TCPO-1 and $\mathrm{CH}_{2} \mathrm{Cl}$ or $\mathrm{CH}_{2} \mathrm{ClCHO}$ from EC-1 are present. Masses expected from abnormal alkylation, resulting from losses of $\mathrm{CH}_{3} \mathrm{OH}$ and $\mathrm{CH}_{2} \mathrm{O}$ to yield $\mathrm{m} / z 189$ and 187 for EC-1 and 257 and 255 for TCPO-1, are not present.

\section{Comparative reactivity study}

Thymidine is generally considered unreactive under conditions where other bases react [28] and although thymidine has been found to be reactive with diazoalkanes $[11,29]$, it was previously found to be unreactive with propylene oxides [3]. Under our reaction conditions, however, each of the propylene oxides react with thymidine to form a product with the same HPLC retention times and UV spectra. The UV spectral identification of N-3 as the site of alkylation was confirmed by NMR, MS and IR spectra of products from the two most reactive epoxides, TCPO and EC. Reactivity was quantitated by HPLC peak heights of the product formed and unreacted material left after reaction (Table I). Taft $\sigma^{*}$ electron withdrawing values 
TABLE I

QUANTITATION OF THYMIDINE REACTIVITY WITH PO

\begin{tabular}{lllll}
\hline $\begin{array}{l}\text { Reaction } \\
\text { of thymi- } \\
\text { dine with }\end{array}$ & $\begin{array}{l}\text { Peak height ratios } \\
\text { dineacted } \\
\text { thymidine/IS }\end{array}$ & Product/IS & $\begin{array}{l}\text { Taft } \sigma^{*} \\
\text { value }^{\mathrm{b}}\end{array}$ & $\begin{array}{l}\text { Mutageni- } \\
\text { city in }^{\mathrm{d}}\end{array}$ \\
\hline PO & $3.2(0.13)$ & $0.0012(0.0018)$ & 0.00 & TA100 $^{\mathrm{c}}$ \\
GL & $2.3(0.089)$ & $0.17(0.02)$ & 0.56 & 0.01 \\
EC & $1.5(0.17)$ & $0.27(0.045)$ & 1.05 & 0.16 \\
TCPO & $0.019(0.0016)$ & $1.1(0.053)$ & 2.65 & 0.31 \\
\hline
\end{tabular}

average of 3 separate reactions with S.D. in parenthesis.

${ }^{b}$ Taft $a^{*}$ values [9] for substituents: $\mathrm{X}=\mathrm{CH}_{3}, \mathrm{CH}_{2} \mathrm{OH}, \mathrm{CH}_{2} \mathrm{Cl}$ or $\mathrm{CCl}_{3}$ on $\mathrm{X}-\mathrm{CH}-\mathrm{CH}_{2}$ ${ }^{\mathrm{M}} \mathrm{Mutagenicity}$ values in revertants/plate $/ \mu \mathrm{M}[10]$.

dIS, internal standard.

[9] for the substituents on the epoxides were used for a prediction of epoxide reactivity and correlated well with either 3-alkylthymidine formation or thymidine remaining after the reaction $(r=0.99)$. The correlation of epoxide reactivity with thymidine to Taft values was comparable to previous correlations obtained with the analytically useful model nucleophiles, 4-( $p$-nitrobenzyl)pyridine and nicotinamide [30]. There was also a good correlation of published Ames Assay TA100 mutagenicity values [10] to 3-alkylthymidine formation $(r=0.99)$ or to unreacted thymidine $(r=0.89)$ after reaction with the epoxides.

In general, our studies were run in methanol in order to facilitate the semi-preparative isolation and characterization of the reaction products of epoxides with thymidine. This also allowed us to include TPCO, the most reactive but least polar epoxide, in our comparative reactivity studies. In addition, the more polar epoxides, GL, PO and EC were reacted with thymidine in aqueous buffer $(\mathrm{pH} 7.0,0.1 \mathrm{M}$ ammonium formate) with analytical isolation of products on a C-18 column. Again the principle reaction products on the basis of their chromatography in this system and in the TLC system as well as by UV peak maxima $(268 \mathrm{~nm})$ and $254 / 280 \mathrm{~nm}$ absorbance ratios (1.0) were indicated to be 3-alkylthymidines.

It is interesting that alkylation was found only at the $\mathrm{N}-3$ of thymidine since this site is not as nucleophilic as either of the oxygen atoms [28]; however accessibility of the sites [31] and nature of the alkylating agent [32] also play an important role. An examination of literature reports for alkylation of thymidine itself or thymidine in DNA shows that indeed the site of alkylation varies with the nature of the alkylating agent $[11,29$, 33-37].

Unfortunately the in vivo persistence and template pairing properties of 3-alkylthymidines have not been investigated. However, a N-3 adduct could presumably lead to mispairing in DNA due to disruption of normal hydrogen 
bonding similar to 3-methylcytidine and 3-methyluridine, which have been indicated to be pro-mutagenic lesions [38].

\section{ACKNOWLEDGEMENT}

This research was supported by Grants R01 CA 25770 from the National Cancer Institute and 9R01 ES 03345 from the National Institute of Environmental Health Sciences, DHHS.

\section{REFERENCES}

1 D.R. Wade, S.A. Airy and J.E. Sinsheimer, The mutagenicity of aliphatic epoxides, Mutat. Res., 58 (1978) 217.

2 S.H. Neau, B.H. Hooberman, S.W. Frantz and J.E. Sinsheimer, Substituent effects on the mutagenicity of phenyl glycidyl ethers in Salmonella typhimurium, Mutat. Res., 93 (1982) 297.

3 K. Hemminki, J. Paasivirta, T. Kurkirinne and L. Virkki, Alkylation products of DNA bases by simple epoxides, Chem.-Biol. Interact., 30 (1980) 259.

4 P.D. Lawley and M. Jarman, Alkylation by propylene oxide of deoxyribonucleic acid, adenine, guanosine and deoxy guanylic acid, Biochem. J., 126 (1972) 893.

$5 \mathrm{~K}$. Hemminki, Fluoreseence study of DNA alkylation by epoxides, Chem.-Biol. Interact., 28 (1979) 269.

$6 \mathrm{~K}$. Hemminki, K. Falck and H. Vianio, Alkylation products of DNA bases by simple epoxides, Arch. Toxicol., 46 (1980) 277.

7 R. Roe, J.S. Paul and P.O'B Montgomery, Synthesis and pmr spectra of 7-hydroxyalkyl guanosine acetate, J. Heterocycl. Chem., 10 (1973) 849.

$8 \mathrm{Z}$. Djurić and J.E. Sinsheimer, Reactivity of propylene oxides towards deoxycytidine and identification of reaction products. Chem.-Biol. Interact., 50 (1984) 219.

9 R.W. Taft, Separation of polar and steric effects in reactivity, in: M.S. New man (Ed.), Steric Effects in Organic Chemistry, Wiley, New York, 1957, pp. 556-659.

$10 \mathrm{~K}$. Hemminki and K. Falck, Correlation of mutagenicity and 4-(p-nitrobenzyl)pyridine alkylation by epoxides, Toxicol. Lett., 4 (1979) 103.

11 J.T. Kusimierek and B. Singer, Reaction of diazoalkanes with 1-substituted 2, 4dioxopurines. Formation of $\mathrm{O}^{2}, \mathrm{~N}-3$ and $\mathrm{O}^{4}$ alkylation products, Nucleic Acids Res., 3 (1976) 989.

12 B. Singer, UV spectral characteristics and acidic dissociation constants of 280 alk yl bases, nucleosides and nucleotides, in: G.D. Fasman (Ed.), CRC Handbook of Biochemistry and Molecular Biology, CRC Press, Cleveland, 1975, 409-447.

13 B. Singer, $\mathrm{M}$. Kroger and $\mathrm{M}$. Carrano, $\mathrm{O}^{2}$ and $\mathrm{O}^{4}$-alkyl pyrimidine nucleosides. Stability of the glycosyl bond and of the alkyl group as a function of $\mathrm{pH}$, Biochemistry, 17 (1978) 1246 .

14 R. Yost, J. Stoveken and W. MacLean, Positive peak identification in liquid chromatography using absorbance ratioing with a variable wavelength spectrophotomeric detector, J. Chromatogr., 134 (1977) 73.

15 H.A. Scoble and P.R. Brown, Reverse phase chromatography of nucleic acid fragments, in: C. Horvath (Ed.), High Performance Liquid Chromatography, Academic Press, New York, Vol. 3, 1983, pp. 1-47.

16 C.W. Gehrke and K.C. Kuo, Chromatography of nucleosides, J. Chromatogr., 188 (1980) 129.

17 H.T. Miles, Infrared spectra in tautomeric structure in $\mathrm{D}_{2} \mathrm{O}$ solution of some pyrimidine nucleosides and nucleotides, Biochim. Biophys. Acta, 22 (1956) 247.

18 L.J. Bellamy, in: The Infra-red Spectra of Complex Molecules, Chapman and Hall, London, 1975, pp. 231-262. 
19 C.L. Angell, An infrared spectroscopic investigation of nucleic acid constituents, J. Chem. Soc., (1969) 504.

20 D.H. Williams and I. Fleming, in: Spectroscopic Methods in Organic Chemistry, 3rd edn., McGraw Hill, London, 1980, p. 65.

21 L. Gatlin and J.C. Davis, Jr., Comparison of ribose and deoxyribose nucleosides by n.m.r. and deductions regarding ribose and deoxyribose nucleic acids, J. Am. Chem. Soc., 84 (1962) 4464 .

22 E.D. Becker, H.T. Miles and R.B. Bradley, Nuclear magnetic resonance studies of methylated derivatives of cytosine. J. Am. Chem. Soc., 87 (1965) 5575.

23 O. Jardetzky and G.C.K. Roberts, in: NMR in Biology, Academic Press, New York, (1981) p. 189.

24 R.M. Silverstein, G.C. Bassler and T.C. Morrill, in: Spectrometric Identification of Organic Compounds, 4th edn., Wiley, New York, 1981, p. 225.

25 C. Hignite, Nucleic acids and derivatives, in: G. Waller (Ed.), Biochemical Applications of Mass Spectrometry, Wiley, New York, 1972, pp. 437-443.

26 J.A. McCloskey, Mass spectroscopy, in: P.O.P. Ts'o (Ed.), Basic Principles of Nucleic Acid Chemistry, Academic Press, New York, 1974, pp. 254-309.

27 R.E. Parker and N.S. Isaacs, Mechanisms of epoxide reactions, J. Chem. Soc., (1959) 737 .

28 R. Bonnaccorsi, A. Pullman, E. Scrocco and J. Tomasi, The molecular electrostatic potentials for the nucleic acid bases: adenine, thymine and cytosine, Theor. Chim. Acta, 24 (1972) 51.

29 P.B. Farmer, A.B. Foster, M. Jarman and M. Tisdale, The alkylation of $2^{\prime}$-deoxyguanosine and of thymidine with diazoalkanes, Biochem. J., 185 (1973) 203.

30 H.J.C.F. Nelis, S.C. Airy and J.E. Sinsheimer, Comparison of the alkylation of nicotinamide and 4-(p-nitrobenzyl) pyridine for the detection of aliphatic epoxides, Anal. Chem., 54 (1982) 213.

31 B. Pullman, Accessibility versus molecular electrostatic potential in B-DNA and Z-DNA, in: Proceedings of the Symposium on Steric Effects in Biomolecules, Eger, Hungary, 1981, pp. 237-246.

32 A. Pullman and A.M. Armbruster, On the affinity of cytosine towards electrophiles, Theor. Chim. Acta, 45 (1977) 249.

33 J.L. Wong and D.S. Fuchs, Reactivities and electronic aspects of nucleic acid heterocycles. II. Diazomethane methylation of uracil and its methyl derivatives, J. Org. Chem., 36 (1971) 848.

34 P.D. Lawley, D.J. Orr, S.A. Shah, P.B. Farmer and M. Jarman, Reaction products from $\mathrm{N}$-methyl-N-nitrosourea and deoxyribonucleic acid containing thymidine residues, Biochem. J., 135 (1973) 193.

35 B. Singer, Methylation and ethylation of uridylic acid and thymidlic acid. Reaction of the ring and phosphate as a function of $\mathrm{pH}$ and alkyl group, Biochem., 14 (1975) 4353 .

36 B. Singer, S. Spengler and W.J. Bodell, Tissue-dependent enzyme-mediated repair or removal of O-ethyl pyrimidines and ethyl purines in carcinogen-treated rats, Carcinogenesis, 2 (1981) 1069.

37 E. Scherer, A.P. Timmer and P. Emmelot, Formation by diethylnitrosamine and persistence of $\mathrm{O}^{4}$-ethyl thymidine in rat liver DNA in vivo, Cancer Lett., 10 (1980) 1.

38 M. Kroger and B. Singer, Ambiguous and transcriptional errors as a result of methylation of N-1 purines and N-3 of pyrimidines, Biochemistry, 18, (1970) 3493 . 